Komissarov, P.V. (2021). Determination of the centric rate of the economic stability domain for manufacturing enterprises. Economy at the crossroads of time. Collection of Scientific Articles. European Scientific e-Journal, 4 (10), 28-36. Hlučín-Bobrovníky: “Anisiia Tomanek” OSVČ.

Комиссаров, П.В. (2021). Определение центрического показателя области экономической стабильности ААя производственных предприятий. Economy at the crossroads of time. Collection of Scientific Articles. European Scientific e-Journal, 4 (10), 28-36. Hlučín-Bobrovníky: “Anisiia Tomanek" OSVČ.

DOI: $10.47451 /$ ecn2021-02-003

The paper will be published in Crossref, ICI Copernicus, Academic Resource Index ResearchBib, J-Gate, ISI International Scientific Indexing, Zenodo, OpenAIRE, BASE, LORY, LUASA, ADL, eLibrary, and WebArchive databases.

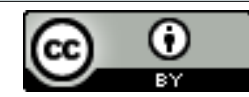

Peter V. Komissarov, PhD student, Admiral Makarov State University of Maritime and Inland Shipping. St. Petersburg, Russia.

\title{
Determination of the centric rate of the economic stability domain for manufacturing enterprises
}

Abstract: The relevance of the topic is related to the problem of determining the strategic stability reserve for production cycles. The study object was economic and production relations transformed into the economic rates of the enterprise. The study aimed to determine the centric indicator of the stability domain. To implement this study, methods of statistical analysis, data grouping, sample ranking, and methods for studying time series components were used. Scientific materials of leading researchers in the space of economic and economic-mathematical analysis were used during the study. The results of the study are intended for specialists and researchers in the field of development and application of mathematical methods in the modelling of economic rates of technological processes at enterprises.

Keywords: economic stability domain, centric rate, production stability rate, strategic security.

Пётр Вениаминович Комиссаров, аспирант, Государственный университет морского и речного флота им. адмирала С.О. Макарова. Санкт-Петербург, Россия.

\section{Определение центрического показателя области экономической стабильности} ААя производственных преАприятий

Аннотащия: Актуальность темы связана с проблемой определения стратегического запаса стабильности Аля производственных циклов. Объектом исследования стали экономикопроизводственные отношения, которые преобразуются в экономическое показатели предприятия. Целью исследования явАянось определение центрического показателя области стабильности. А^я реализации данного исследования были применены методы статистического анализа, группировка Аанных, ранжирование выборки, методы исследования компонент временного ряда. В ходе исследования были использованы научные материалы ведущих исследователей в области экономического и экономико-математического анализа. Результаты исследования предназначаются Аля специалистов и исследователей в области разработки и применения математических методов в моделировании экономических показателей технологических процессов на предприятиях.

Ключевые слова: область экономической стабильности, центрический показатель, показатель производственной стабильности, стратегическая безопасность. 


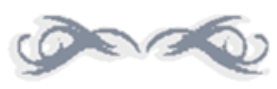

\section{Introduction}

The meaning of opening and running any business is to make a profit. Entrepreneurs and companies need to assess the prospects of the industry before investing in a startup. It is also necessary when developing and bringing new products or services to the market. Understanding the profitability of different types of products, a specialist can correctly reallocate the company's resources to more promising areas and remove unprofitable positions.

The stability domain in this aspect becomes one of the most important indicators. It indicates at what volume of production an industrial company will get the most effective results for sustainable development. In this area, the profit has a certain distance from the break-even point indicators.

This indicator is necessary to understand the range of output volume or revenue size. There the company can operate normally. It does not only cover costs but also acquires additional resources for its stable development. If the indicators are below the critical point of the stability area, it means that the financial indicators are rushing to the break-even point (BEP), which means an increase in the risk of bankruptcy.

The stability domain should be calculated before launching a new business project and at each stage of its development. This will increase the elasticity of economic indicators and become a tool to prevent particularly significant risks for the enterprise.

A comprehensive calculation of the stability domain allows:

- more accurately determine the profitability of a new product, taking into account what equipment and technologies are used by this company, what volume of products can be produced and sold;

- exclude maximum risk indices from the operation (0.65-1);

- correctly allocate the set of prospective indicators by taking into account medium (0.35$0.64)$ and small (0.1-0.34) risks;

- enter a set of these indicators into a set of key indicators in any project feasibility study;

- plan production volumes taking into account changes in both external and internal factors without a sharp change in production indicators, which increases the risk of disruption of production chains;

- form the delta (range) of the cost price and, consequently, the selling value of the product of production taking into account the needs of the enterprise and the formation of a reserve;

- optimize production chains and business processes without compromising final targets.

To calculate the area of economic stability of an enterprise's production, it is necessary to calculate a centric indicator (the centrally directed domain point), which will later form the function of determining the area of production stability taking into account additional indicators including the stability point (Komissarov, 2020).

The study subject was the indicators allowing to determine their totality as an economic stability domain of production.

The study object was the economic and production relations transformed into the economic indicators of the enterprise. 
The study aimed to determine the general parameters of the stability domain.

Based on the purpose of the study, the following tasks were set:

- give the concept of the area of stability;

- develop a method for determining the stability parameters of a manufacturing enterprise;

- determine the centric parameter of the stability domain for production-type enterprises.

To implement this study, mathematical and statistical analysis, data grouping, sample ranking, and methods for studying time series components are used.

The research used scientific materials of R.E. Bellman, E. Polak, L.A. Zadeh, and other leading researchers in the field of fuzzy sets and mathematical methods for calculating various components.

The study results are targeted at specialists and researchers in the field of development and application of mathematical methods in the modelling of economic indicators of technological processes at enterprises.

\section{Methods and Materials}

The stability domain is a set of economic indicators of the volume of production and sales of products, in which expenses will be offset by income in a certain positive proportion, called income, which allows the enterprise to maintain a balance between the costs of development and the costs of current production.

Consequently, the stability domain is represented as a range of economic indicators, which remains distinctive from the break-even point in its lowest dimension and does not tend to maximize production turnover, i.e., to marginal income point, in the highest dimension.

The stability indicators set is concentrated around the stability point, which is the most correct indicator of the desired calculus for the product under study. The stability domain concept is based on the calculations of the stability point. However, it is a new economic concept firstly published in the results of these studies.

The stability domain can include an indefinite set of stability indicators having various combinations of the following indicators:

- $\quad$ production stability rate (PSR);

- $\quad$ production innovation rate (PIR);

- $\quad$ effective product growth rate (EPGR);

- $\quad$ product components cost rate (PCCR);

- $\quad$ effective wage fund rate (EWFR).

Thus, the stability domain provides an innovative view of production and expands the possibilities of a comprehensive analysis of production increasing the correctness and competence of the final research results.

\section{Solving a practical problem}

As part of the study of determining the centric indicator of the stability area for manufacturing enterprises, the parameters of stability indicators were determined based on such conditions as ease of use, the brevity of the indicator and breadth in use. 
The production stability rate (PSR) is an indicator of trends in the correlation of the general parameters of annual or quarterly production indicators, i.e., the breadth of the range is an approximation to the average median indicator of this set. The coefficient exists in the range from 0.0001 to 2 . The closer the coefficient is to 1 , the more stable production is economical. The innovation sustainability levels can be interpreted as quarts:

- from 0,950 to 1,050 are very high indicator,

- from 0,901 to 0,949 or from 1,051 to 1,099 are high indicator,

- from 0,851 to 0,900 or from 1,100 to 1,149 are average indicator,

- from 0,85 and below or from 1,15 and above are low indicator.

Let's consider an example of interpreting the performance indicators of the plan in the factor of production sustainability using quarterly parameters for two years (Table 1).

The average plan implementation rate is 1,014.

The plan implementation delta is $13 \%$.

Production stability factor is

$1,014 *(1-0,13)=1,014 * 0,87=0,88$.

Therefore, in this case, the production stability rate is 0.88 , i.e., it shows the average stability of production.

The production innovation rate (PIR) is an economic indicator of the trend in the share of financing of innovative developments, modernization of production and its management, and staff training. According to the condition, the financing share is determined by the enterprise itself based on the specifics of the production industry and the indicators of the last 10-15 years.

This percentage rate is taken as 1 . The rate exists from 0.001 to 2 . If the rate is closer to 1 , the innovation of production is more stable (Table 2). The innovation sustainability levels can be interpreted in quarts:

- from 0,950 to 1,050 are very high rate,

- from 0,901 to 0,949 or from 1,051 to 1,099 are high rate,

- from 0,851 to 0,900 or from 1,100 to 1,149 are average rate,

- from 0,85 and below or from 1,15 and above are low rate.

The production innovation rate is 1.035 . Therefore, in this case, the rate shows very good innovation stability.

The effective product growth rate (EPGR) is an economic indicator of the trend in the yield per unit of production, calculated from the difference between the selling price and the cost of a production unit. For the economic growth of an enterprise to be elastic, the profitability growth of a production unit should not be predominantly higher than the growth of inflation, i.e., it should be as close as possible to 1 when calculating the ratio of the profitability growth to the annual rate of inflation.

The rate exists from 0.001 to 2 . If the rate is closer to 1 , the product growth is more efficient. Efficiency levels can be interpreted in quarts:

- from 0,950 to 1,050 are very high rate,

- from 0,901to 0,949 or from 1,051 to 1,099 are high rate,

- from 0,851 to 0,900 or from 1,100 to 1,149 are average rate,

- from 0,85 and below or from 1,15 and above are low rate (Table 3). 
The effective product growth rate is 1,03 . Therefore, in this case, the rate shows a very high efficiency.

The product components cost rate (PCCR) is an economic indicator of the trend in the cost of all components of the final product that are purchased from the external environment of the enterprise, taking into account the inflation rate. For the economic growth of an enterprise to be elastic, the growth in the cost of production components must mathematically consider the ratio with inflation indicators, that is, be as close as possible to 1 when calculating the ratio of the growth of profitability to the annual inflation rate.

The rate exists from 0.001 to 2 . If the rate is closer to 1 , the product growth is more efficient. Efficiency levels can be interpreted in quarts:

- from 0,950 to 1,050 are very high rate,

- from 0,901 to 0,949 or from 1,051to 1,099 are high rate,

- from 0,851 to 0,900 or from 1,100 to 1,149 are average rate,

- from 0,85 and below or from 1,15 and above are low rate (Table 4).

The product components cost is 1,024 . Therefore, in this case, the rate shows very high efficiency.

The effective wage fund rate (EWFR)is an economic indicator of the trend in the cost of labour of all employees of the enterprise taking into account the inflation rate. For the economic growth of an enterprise to be elastic, the growth in the cost of labour should mathematically consider the ratio with inflationary indicators, i.e., be as close as possible to 1 when calculating the ratio of the growth of the wage fund to the annual inflation rate.

The rate exists from 0.001 to 2 . If the coefficient is closer to 1 , the wage fund is more efficient. Efficiency levels can be interpreted in quarts:

- from 0,950 to 1,050 are very high rate,

- from 0,901 to 0,949 or from 1,051to 1,099 are high rate,

- from 0,851 to 0,900 or from 1,100 to 1,149 are average rate,

- from 0,85 and below or from 1,15 and above are low rate (Table 5).

The effective wage fund rate is 1,028 . Therefore, in this case, the rate shows very high efficiency.

\section{Results}

Based on the methods developed in the course of the study for calculating the five developed rates to determine the stability domain for production enterprises, a formula to calculate the centric rate (CR) of the production stability domain was developed:

$$
C R=P S R * P I R * E P G R * P C C R * E W F R
$$

There:

PSR - production stability rate,

PIR - production innovation rate,

EPGR - effective product growth rate,

PCCR - product components cost,

EWFR - effective wage fund rate. 
According to the definition of the equation components, the CR should tend to 1 . If this rate is closer to 1, the production enterprise work is more stable. Efficiency levels can also be interpreted in quarts:

- from 0,950 to 1,050 are very high rate,

- from 0,901 to 0,949 or from 1,051 to 1,099 are high rate,

- from 0,851 to 0,900 or from 1,100 to 1,149 are average rate,

- from 0,85 and below or from 1,15 and above are low rate.

During the study, the simulated rate of the average production organization was considered by means of the developed formula:

$$
C R=0.88 * 1,035 * 1,03 * 1,024 * 1,028
$$

$\mathrm{CR}=0,9875$.

Thus, the simulated enterprise exhibits very high production stability and the stability domain is quite far from the break-even point (BEP).

Based on the developed rates and the method for determining the centric parameter of economic stability, the centric rate of the economic stability domain for manufacturing enterprises was verified.

\section{Discussion of Results}

The developed rates are not final. Other areas of the company's activities may also be considered, or this method may be extrapolated to service companies. Therefore, the formula for determining the centric rate of the stability domain can be used to analyze the economic activity of enterprises in various fields of entrepreneurship, as well as state and municipal financing.

It is proposed to consider the following issues:

1. Can additional rates of the enterprise's economic state be determined that are applicable in the developed method for calculating the centric parameter of the stability area?

2. What economic and other rates can be analyzed using this method for service enterprises?

\section{Conclusion}

Thus, during the study course, the stability domain concept was given as a set of economic rates of the production volume and sales of products, in which expenses will be compensated by income in a certain positive proportion, called income. It allows the enterprise to maintain a balance between the development costs and the current production costs.

A method for determining the manufacturing enterprise's stability rates was developed and presented. It includes five general weighted rates: production stability rate, production innovation rate, effective product growth rate, product components cost rate, and effective wage fund rate.

Based on the developed parameters of the production enterprise's stability, a formula for determining the centric rate of the production-type enterprises' stability domain was developed. So, the effectiveness of this solution method was proved. 


\section{References:}

Bellman, R.E., \& Zadeh, L.A. (1970). Decision making in a fuzzy environment. Management Science, 17, 4, 141-164.

Bellman, R.E., \& Zadeh, L.A. (1977). Local and fuzzy logics. Modern Uses of Multiple-Valued Logic, 103-165. The Netherlands: D. Reidel Publishing Co.

Chernov, V.P. (2002). Mathematics for senior managers. St. Petersburg: Nauka.

Krass, M.S., \& Chuprykov, B.P. (2019). Mathematics in Economics: mathematical methods and models. Moscow: Yurayt Publishing House.

Golik, E.S. (Ed.) (2005). Mathematical methods of system analysis and decision-making theory. Part II: Textbook. St. Petersburg: SZTU.

Guts, A.K. (2016). Mathematical logic and the theory of algorithms. Textbook. Ed. 3rd, ISPR. Moscow: LENAND, 2016.

Kim, E.S. (2016). Analysis of existing software to automate the operation of the enterprise. Technology. Technologies. Engineering, 1, 11-14.

Kolesnichenko, S.V. (2017). Information and statistical analysis of the processes of functioning of complex technical and socio-economic systems. Proceedings of the 16th MNPK Analysis and Forecasting of Control Systems in Industry and Transport, 336-348. St. Petersburg.: Fedorov Publishing House.

Kolmogorov, A.N., \& Dragalin, A.G. (2017). Mathematical logic: Introduction to mathematical logic. Textbook. Moscow: LENAND.

Komissarov, P.V. (2018). Actual issues of modelling production processes of complex technical and socio-economic systems. Collection of works of the GUMRF. St Petersburg: GUMRF, 6771.

Komissarov, P.V. (2018). Method of complex assessment of economic indicators of the enterprise. Collection: Analysis and forecasting of management systems in industry and transport, 57-58. St Petersburg: Astra.

Komissarov, P.V. (2020). Relevance of the application of the theory of fuzzy sets in the calculation of the strategic security of a complex technical system. Actual issues of modern science. No. 1. Vol. 2, add. Collection of Scientific Articles, 6, 2, 54-63. European Scientific eJournal. Hlučín-Bobrovníky: "Anisiia Tomanek" OSVČ.

Volokhin, D.V. (2020). The relevance of the representation of fuzzy knowledge using fuzzy sets. Scientific Aspect, 2, 16, 2026-2029. Samara: Aspekt.

Zadeh, L.A. \& Polak E. (Eds.). (1969). System Theory. Inter-University Electronics Series, 8. New York: McGraw-Hill.

Zemskov, A.V., \& Shilkina I.D. (2018). Economic and mathematical models. Educational and methodological guide for laboratory work. St. Petersburg: Publishing house of S.O. Makarov GUMRF. 


\section{Appendix}

Table 1. Quarterly performance rate of the financial production plan

\begin{tabular}{|c|c|c|c|c|c|c|c|c|}
\hline Year & \multicolumn{4}{|c|}{2019} & \multicolumn{4}{c|}{2020} \\
\hline Quarter & 1 & 2 & 3 & 4 & 1 & 2 & 3 & 4 \\
\hline Execution & 0,94 & 0,98 & 0,97 & 1,09 & 1,07 & 1,05 & 0,96 & 0,99 \\
\hline
\end{tabular}

Table 2. Annual performance rate of the average financing share of enterprise's innovative activity

\begin{tabular}{|c|c|c|c|c|}
\hline Year & 2017 & 2018 & 2019 & 2020 \\
\hline Execution & 0,995 & 0,984 & 1,074 & 1,086 \\
\hline
\end{tabular}

Table 3. Annual indicators for calculating the unit yield rate

\begin{tabular}{|c|c|c|c|c|}
\hline Year & 2017 & 2018 & 2019 & 2020 \\
\hline Inflation rate & $2,03 \%$ & $2,10 \%$ & $2,25 \%$ & $2,19 \%$ \\
\hline Yield per unit of output & $2,17 \%$ & $2,08 \%$ & $2,22 \%$ & $2,35 \%$ \\
\hline Execution & 1,069 & 0,990 & 0,987 & 1,073 \\
\hline
\end{tabular}

Table 4. Annual indicators for calculating the cost rate of components of a manufactured product unit

\begin{tabular}{|c|c|c|c|c|}
\hline Year & 2017 & 2018 & 2019 & 2020 \\
\hline Inflation rate & $2,03 \%$ & $2,10 \%$ & $2,25 \%$ & $2,19 \%$ \\
\hline Increasing the cost of components & $2,21 \%$ & $2,12 \%$ & $2,18 \%$ & $2,27 \%$ \\
\hline Execution & 1,089 & 1,001 & 0,969 & 1,037 \\
\hline
\end{tabular}

Table 5. Annual indicators for calculating the efficiency coefficient of the wage fund rate

\begin{tabular}{|c|c|c|c|c|}
\hline Year & 2017 & 2018 & 2019 & 2020 \\
\hline Inflation rate & $2,03 \%$ & $2,10 \%$ & $2,25 \%$ & $2,19 \%$ \\
\hline Increasing the cost of components & $2,20 \%$ & $2,10 \%$ & $2,30 \%$ & $2,20 \%$ \\
\hline Execution & 1,083 & 1,000 & 1,022 & 1,005 \\
\hline
\end{tabular}

